\title{
Modified Raktamokshna as Chinese cupping therapy in acute pain management of Lumbar spondylosis - A Rare Case Report
}

\author{
Madhuri Rai $^{1}$ Tukaram Dudhamal ${ }^{2}$ \\ ${ }^{1}$ MS Scholar, ${ }^{2}$ Associate Professor, \\ Department of Shalya Tantra, Institute for Post Graduate Teaching and Research in \\ Ayurveda, Gujarat Ayurved University, Jamnagar, Gujarat, India
}

\begin{abstract}
:
Due to vitiation of vata spine will assume the shape of bamboo with limited or absent Chalaguna of Vata. This condition can be correlated with acute lumbar canal stenois. Raktamokshana is recommended in Ayurveda for such type of crippling disorder. In this case report a male patient of 54 years having sever low back pain which radiating in to both legs since 1 year, painful restricted movement of lumbar joint, patient was unable to walk for prolong distance since 4 months consulted to Ayurveda shalya OPD. He had taken allopathic pain killer and finally orthopedic surgeon suggested for surgery. In this case study patient was managed with raktamokshana by wet type of Chinese cupping therapy in 2 sittings at 15 days interval. After first sitting of cupping $50 \%$ pain relief was found and after second sitting patient was able to walk without pain in lumbar region.
\end{abstract}

Key Words: Alabu, Cupping, Katigatavata, Lumbar spondylosis, Raktamokshana, Shringa

\begin{tabular}{|l|l|}
\hline Received: 10.06.2018 & Revised: 18.06.2018 Accepted: 27.06.2018 \\
\hline & $\begin{array}{l}\text { CORRESPONDING AUTHOR } \\
\text { Madhuri Rai } \\
\text { MS Scholar } \\
\text { Dept. of Shalya Tantra. IPGT\&RA, Gujarat Ayurved } \\
\text { University, Jamnagar, Gujarat, India } \\
\text { Email: madobs01@gmail.com } \\
\text { Mobile: +918989140906 }\end{array}$ \\
\hline
\end{tabular}




\section{Introduction:}

KatigataVata (Lumbar spondylosis) is a clinical condition develops when the vitiated Vayu becomes localized in Kati Pradesha. Low back pain is now ranked $2^{\text {nd }}$ to headache as the most common location of pain. Four out of every five adults experience at least one bout of back pain at some time in their lives. In India, nearly 60 $\%$ of the people have significant back pain. Lumbar spondylosis is responsible for about $10 \%$ of all back pain. ${ }^{[1]}$ Among Parasurgical procedures Raktamokshana is accepted as half of the therapeutic measure in ShalyaTantra. ${ }^{[2]}$ Raktamokshana is one of the fascinating subject and satisfactory answer for lumbar spondylosis. Shring aavcharana or alabu avachaan type of Raktamokshana can be correlated with Chinese cupping method. ${ }^{[3]}$ The suction through specific cupped instrument was used since Sushruta's time for the treatment of musculoskeletal diseases. ${ }^{[4-6]}$

Two types of cupping therapy is being practiced in Chinese traditional medicine which are dry and wet cupping. In dry cupping, the suctioning cups simply pulls the local skin to create vacuum into the cup and in wet cupping same technique was used but the difference is that pricking on skin so that blood is drawn into cups. Reports indicated that cupping has frequently used to relief back pain and also it helps to release harmful toxins by stimulating lymphatic system and clearing the blood vessels. ${ }^{[7]}$

\section{Case Report:}

A 54 years-old male patient visited to outpatient department (OPD) of ShalyaTantra, having sever low back pain which radiating to both legs since 1 year, painful restricted movement of lumbar joint, patient was unable to walk for prolong distance since 4 months. Patient was non-hypertensive, nondiabetic and did not have any symptoms of endocrinal disorders and no operative history and no any other systemic disease. Patient reported history of taking allopathic analgesics but did not get rid of from pain. The pain relief was temporary so ortho surgeon advised for laminectomy. So he visited to IPGT\&RA, Ayurved Research Hospital, Jamnagar.

On examination the restricted movement of leg painful forward bending was observed. Schobar test distance increases $3 \mathrm{~cm}$, Straight leg raising (S.L.R.) test /Lasegue sign was noted and was found $15^{\circ}$ in the left leg and $75^{\circ}$ in right leg. The laboratory investigation for blood was done before and after the treatment and was found within normal limits. Special investigations for HIV, HBsAg was done. X-Ray of lumbosacral spine, AP and Lateral view shows Lumbar spondylotic changes with multiple anterior osteophytes and L4-L5 \& L5-S1 level show prolapsed disc s/o PID IV disc were noted.

\section{Methodology of cupping:}

After written consent the patient was treated with wet cupping in sitting by 7 days interval. Local Snehan was done with Tila Taila followed by Nadi Swedana with Dashmool kwath was done on the lower 
back region to improve circulation at applied region. In first sitting 3 cups were applied at back region and three cups were applied at both legs (Fig-1). In second sitting (after 7 days) again 3 cups at lumbar region and 3

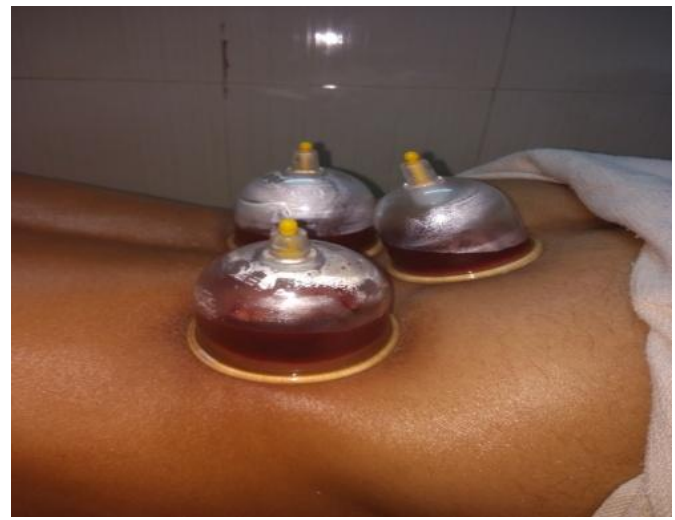

Fig.-1:

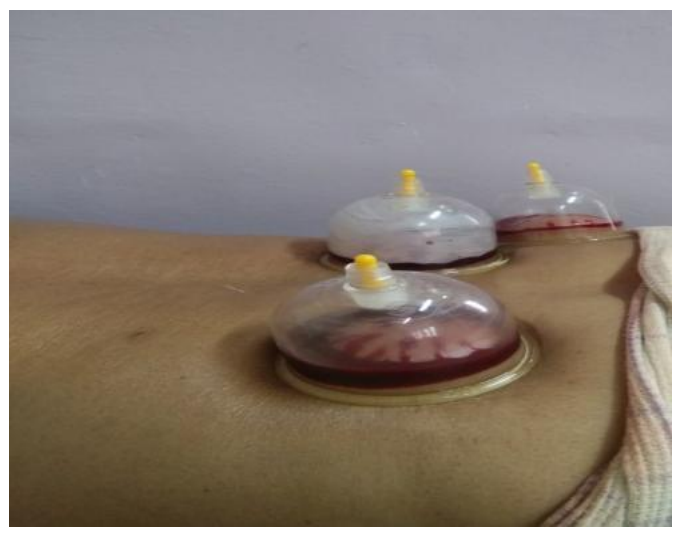

Fig.-2: $\quad 2^{\text {nd }}$ sitting of cupping

Result and Discussion:

After $1^{\text {st }}$ sitting, patient got $40 \%$ relief in Katishula, Katistambha , Katisuptata , Akunchan Prasarane Pravrittisavedana. Schobar test distance increased $0.5 \mathrm{~cm}$. Forward flexion was increased up to $70^{\circ}$. S.L.R was increased up to $45^{\circ}$ in left leg and 75 in right leg. After $2^{\text {nd }}$ sitting he got $70 \%$ relief in above symptoms. There is significant change in walking for prolong distance. He can walk and can perform his cups at right leg only were applied as pain was only in right leg after fist sitting (Fig-2). The whole procdure was adopted as $\mathrm{Dr}$. Nandini et.al. ${ }^{[8]}$

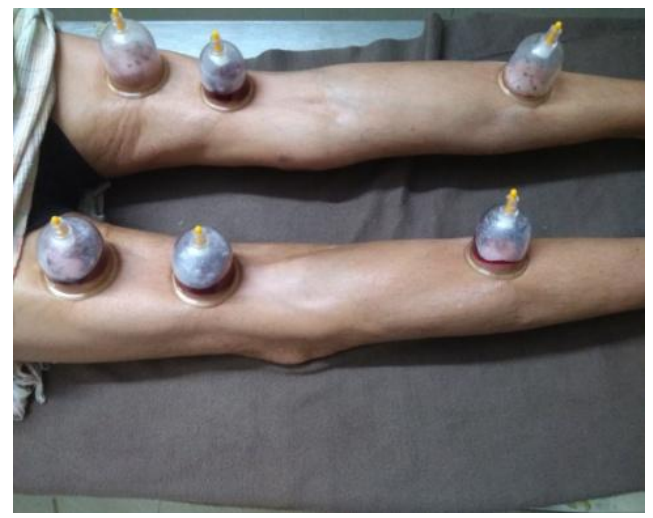

$1^{\text {st }}$ sitting of cupping

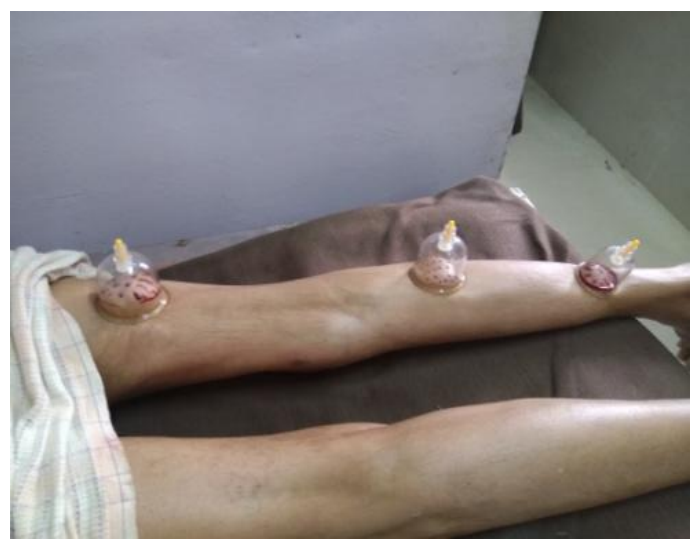

daily routine work without pain and comfortably.

In Ayurveda Raktamokshana is predominantly indicated in vata vyadhi having anubandha with kapha. ${ }^{[9]}$ Hypothetically it can be said that the Raktamokshana is useful in patients when there is Avarana Janya Samprapti in Lumbar spondylosis. Raktmokshana by Shringaavcharana is also indicated in Vatdushit Rakta Vyadhi in Sushrut Samhita. ${ }^{[10]}$ 
Chinese cupping therapy can be equated with the Shringa as well as Alabu. It works on the principle of vacuum extraction. Cupping targets soft tissue by applying local pressure to pain points and areas of swelling. It helps to extract blood from the body which may be harmful and in turn, overcome the potential adverse effects, leading to physiological well-being. It is thought to act mainly by increasing local blood circulation and relieving the painful muscle tension. It mainly involves improving microcirculation, promoting capillary endothelial cell repair, accelerating granulation, and angiogenesis in the regional tissues. This helps in normalizing the patient's functional state and progressive muscle relaxation. Cupping is the best deep tissue massage.

\section{Conclusion:}

Raktamokshana by Chinese cupping is an office procedure, effective, simple, and safe for pain management of patients having lumbar spondylosis.

\section{References:}

1. Middleton Kimbereley et al., Lumbar Spondylosis: Clinical presentation \& treatment approaches , Curr Rev. Musculoskeletal Med,2009, Jun; 2(2): 94-104

2. Sushruta, Sushruta Samhita, Nibandha Sangraha, Sharira Sthana 8/23 Yadavji Trikamji Reprint edition, Chaukhamba surbharti Prakashana, Varanasi,. 2010; p. 383.

3. Shastri A. Sushruta Sutra Sthana 13/5 Sushrut Samhita, Sushrut Samhita,
Poorvardh, Chaukhambha publication, Varanasi. 2010; p 57.

4. Abele, J. Das Schröpfen. Eine bewährte alternative Heilmethode Taschenbuch: Urban \& Fischer, Mchn (1996).

5. Chirali, I.Z. Scott, J. Cupping Therapy: Traditional Chinese Medicine. Elsevier Health Sciences, Philadelphia. 1999; 35.

6. Nielsen, A. Gua Sha. A Traditional Technique for Modern Practice. Churchill Livingstone, New York; 1995; 2-5.

7. Foley, N. Teasell, R. Bhogal, S.K. Kruger, E. Graham R. Miscellaneous Treatments: 20, 21, 22 (2012).

8. Nandini D, Dudhamal TS. Effect of Cupping Therapy in Gridhrasi (Sciatica)A case report. Indian Journal of Ancient Medicine and Yoga. 2016;9 (3): 115118.

9. Pandey K. Charaka, Charaka Samhita, Sutra Sthana 24/18edition reprint 2008, Chaukhamba Bharti Academy, Varanasi. 2008; p 448.

10. Shastri A. Sushruta Sushrut Samhita, Sutra Sthana 13/5, Edition:Reprint. Chaukhambha publication, Varamnasi. 2010; p. 57.

Guarantor: Corresponding author is guarantor of this article and its contents.

Conflict of interest: Author declares that there is no conflict of interest.

How to cite this article: Rai M, Dudhamal TS. Modified Raktamokshna as Chinese cupping therapy in acute pain management of Lumbar spondylosis - A Rare Case Report. Int. J AYUSH CaRe. 2018; 2(2):3134 